УДК 661.1:541.18

\title{
ИССЛЕДОВАНИЕ ДИСПЕРГИРУЮЩЕГО ЭФФЕКТА ПОЛИМЕРНЫХ ПОВЕРХНОСТНО-АКТИВНЫХ ВЕЩЕСТВ В АКРИЛОВЫХ ДИСПЕРСИЯХ, ПРИМЕНЯЕМЫХ ДЛЯ ОКРАСКИ УСТЬЕВОЙ АРМАТУРЫ НЕФТЯНЫХ СКВАЖИН
}

\author{
Дюрягина Антонина Николаевна', \\ adyuryagina@inbox.ru \\ Луценко Аида Александровна', \\ |-a.13@mail.ru
}

\author{
Тюканько Виталий Юрьевич², \\ vetal3333@mail.ru \\ 1 Северо-Казахстанский Университет им. М. Козыбаева, \\ Республика Казахстан, 150000, г. Петропавловск, ул. Абая, 18. \\ 2 АО «Казнефтегазмаш» по лакокрасочным покрытиям, \\ Республика Казахстан, 150000, г. Петропавловск, ул. Новая, 122.
}

\begin{abstract}
Актуальность работы обусловлена необходимостью создания новых воднодисперсных лакокрасочных материалов с повышенным эксплуатационным ресурсом, согласно жёстким требованиям ПАО «НК «Роснефть» для защиты от атмосферной коррозии устьевой арматуры нефтяных скважин. В связи с ужесточением экологических требований во многих странах мира возросло использование воднодисперсных лакокрасочных материалов. Так, один из крупнейших производителей устьевой арматуры нефтяных скважин в Республике Казахстан - АО «Казнефтегазмаш» - принципиально использует для окраски своих изделий только воднодисперсные акриловые лакокрасочные материалы: грунтовку "Уникор-М» ТУ 2316-002-0-31953544-96 и краску «Акрэм-Металл» ТУ 2316-003-0-31953544-96. Однако основные российские нефте- и газодобывающие компании, в частности ПАО «НК «Роснефть», ПАО «Газпром» и др., в последнее время резко ужесточили требования к сроку защитного ресурса лакокрасочных покрытий. Так, согласно технологической инструкции ПАО «НК «Роснефть» № П2-05 ТИ-0002 «Антикоррозионная защита металлических конструкций на объектах нефтегазодобычи, нефтегазопереработки и нефтепродуктообеспечения компании», минимальный защитный ресурс лакокрасочных покрытий в зависимости от условий эксплуатации, составляет не менее 10 лет. А применяемые $A O$ «Казнефтегазмаш» акриловые лакокрасочные материалы обеспечивают защитный ресурс покрытий не более 5 лет. Поэтому с учетом всего вышеперечисленного нами предпринята попытка увеличения защитного ресурса лакокрасочного покрытия путем получения более однородного распределения пигмента в полимерной матрице, за счет применения поверхностно-активных веществ.

Целью работы являлось изучение влияния полимерных поверхностно-активных веществ на диспергирование пигмента (диоксида титана) в водной дисперсии акрилового полимера.

Методы: компьютерно-оптическая микроскопия и математическое моделирование.

Результаты и выводы. Представлены результаты исследования влияния полимерных поверхностно-активных веществ марки TEGO: Glide 100 (полиэфирсилоксановый сополимер) и Dispers715w (полиакрилат натрия), на диспергирование диоксида титана (марка R-02) в водной акриловой композиции. Показано, что Glide 100 и Dispers 715w при содержании в композиции от 0,25 до 0,5 г/дм³ улучшают диспергирование пигмента. Наиболее эффективной добавкой является Dispers 715w, при этом диаметр частиц пигмента уменьшается в два раза (с 8 до 4 мкм). Выведены уравнения, описывающие влияние содержания и вида поверхностно-активных веществ на диаметр частиц пигмента, и на их основе построены номограммы. Разработанные лакокрасочные материалы могут использоваться для окраски устьевой арматуры нефтяных скважин.
\end{abstract}

\section{Ключевые слова:}

Защитные покрытия, лакокрасочные покрытия, защита от коррозии устьевой арматуры нефтяных скважин, поверхностно-активные вещества, диспергирование, водно-акриловая дисперсия, диоксид титана, суспензия.

\section{Введение}

В промышленности для защиты устьевой арматуры нефтяных скважин от атмосферной коррозии применяются лакокрасочные материалы (ЛКМ) [1-4]. В последнее время, в связи с вредностью и токсичностью применяемых растворителей, постоянно снижается использование органорастворимых ЛКМ. Одним из их заменителей являются воднодисперсные ЛКМ. Так АО «Казнефтегазмаш» использует для окраски устьевой арматуры только воднодисперсные акриловые ЛКМ: грунтовку «Уникор-М» ТУ 2316-002-0-31953544-96 и краску «Акрэм-Металл» ТУ 2316-003-0-31953544-96.
Поэтому с учетом всего вышеперечисленного нами предпринята попытка увеличения времени защитного ресурса лакокрасочного покрытия за счет применения поверхностно-активных веществ (ПАВ). Введение ПАВ в ЛКМ является перспективным направлением для интенсификации процессов дезагрегации (расклинивающий эффект $\mathrm{Pe}$ биндера) и стабилизации тонкодисперсных состояний во времени [5]. Это было установлено работами академика П.А. Ребиндера [6-8] и в дальнейшем развито сотрудниками его школы - А.Б. Таубманом и С.Н. Толстой $[9,10]$, исследовавших взаимодействие пигментов с полимерами на границе раз- 
дела фаз. Оказалось, что дисперсность частиц пигмента при совмещении с полимером может как улучшаться, так и ухудшаться, кроме того, она зависит от химической природы обоих компонентов $[11,12]$. Взаимодействуя друг с другом через прослойки поверхностно-активного вещества, твердые частицы образуют развитую структуру, на которой, как на каркасе, образуется вторичная структура ориентированного полимера [13, 14]. Несмотря на большое количество работ [15-17], посвященных исследованию влияния ПАВ на свойства композиционных материалов, влияние полимерных поверхностно-активных веществ на процессы диспергирования пигментов еще недостаточно изучено, в этой связи представлялось целесообразным исследовать влияние ионогенных полимерных ПАВ марки TEGO: Glide 100 (полиэфирсилоксановый сополимер), Dispers715w (полиакрилат натрия), на развитие процессов дезагрегации диоксида титана (марка R-02) в композициях на основе акрилового пленкообразующего (ТУ 2316-014-88753220-2006) и полярного растворителя (вода).

\section{Экспериментальная часть. Методика и проведение экспериментов}

Для количественной оценки диспергирующего эффекта ПАВ предпочтителен метод оптической микроскопии [18], позволяющий непосредственно зафиксировать линейные размеры и конфигурацию отдельных дисперсий, а также определить фракционный состав и качественно-количественные закономерности изменения их характеристик в лакокрасочных суспензиях. Решение этих задач, в рамках традиционного микрооптического анализа, ограничивают существенные затраты времени, трудоемкость и недостаточная точность, что связано с преобладанием визуальных оценок, рутинных операций как на стадии зондирования, так и на стадии обработки изображений. Вышеизложенное определило целесообразность сопряжения возможностей микрооптических анализаторов и компьютерных систем на техническом и методологическом уровне [19]. Для адекватного переноса изображения, наблюдаемого в окуляре микроскопа, использовали электронную преобразователь-насадку с кратностью увеличения $\times 35$, которая снабжена стандартным USB портом и программным пакетом. Принцип работы электронного видеоокуляра аналогичен принципу работы фотоэлемента и заключается в преобразовании световой энергии в электрическую. Системный блок насадки с малоформатными ПЗС-камерами трансформирует фиксируемые в окуляре микроскопа изображения в сигналы, приемлемые для восприятия системой WindowsXP в персональных компьютерах.

Электронные насадки по конфигурации совместимы с традиционными микроскопами. В разработанной нами системе использовали микроскоп CARLZEISS 451422. На первом этапе в рамках используемого программного пакета «Спектр диффе- ренциального распределения» методом непрерывного сканирования осуществляли распознавание отдельных твердофазных частиц пигментана микроизображениях исследуемых композиций, с последующим переносом их в системный блок компьютера и сохранением (документирование). На втором этапе в автоматическом режиме осуществляли обработку микроизображений с получением количественной информации об удельном количестве частиц (на единицу площади), их геометрических параметрах (линейные размеры, конфигурация, площадь) и, наконец, в целом о фракционном составе. Алгоритм обработки данных включал следующие основные операции:

1) бинаризацию сохраненного ранее изображения - преобразование изображения в чёрно-белое;

2) распознавание при непрерывном сканировании и сортировку отдельных дисперсий по количеству $(N$, ед), крупности и фракционному составу $(P, \%)$ путем считывания их площади в пикселях ( $S$, пкс). Трансформация расчетного показателя размера частиц, выраженного в пикселях в метрические единицы (мкм);

3) расчет интегральных и дифференциальных характеристик распределения частиц (по их количеству, линейным параметрам и площади) и их отражение в виде диаграмм, функций распределения или же в табличной форме в зависимости от заданных (в исследованиях) параметров оптимизации;

4) вывод функциональных зависимостей (в форме уравнений или графиков) разностных интегральных и дифференциальных характеристик распределения частиц (по количеству, линейным размерам или площади) в зависимости от количественного содержания пленкообразующего и ПАВ в композициях.

При этом составы суспензий оптимизировали по количественному содержанию в них твердой фазы в зависимости от степени дисперсности частиц и распределения их по классам крупности. Одновременно, для формирования однородных и стабилизированных во времени пленок (по толщине и плотности распределения дисперсий на поверхности предметного стекла), определили требуемые характеристики статической нагрузки (масса, продолжительность выдержки) на покровное стекло. Это позволило нивелировать влияние деформационных эффектов, вызываемых вариациями состава суспензий (по содержанию твердого) и трехосным сжатием (по высоте и плоскости) из-за развития во времени сопутствующих процессов (испарение дисперсионной среды).

Испытание комплекса на стандартизированных объектах в статическом и динамическом (во времени) режимах показало, что погрешность измерений не превышает 1,3 \% (отн.). Общая продолжительность микрооптического анализа (от съемки образцов до выдачи результатов) ограничивалась 3-4 минутами. 


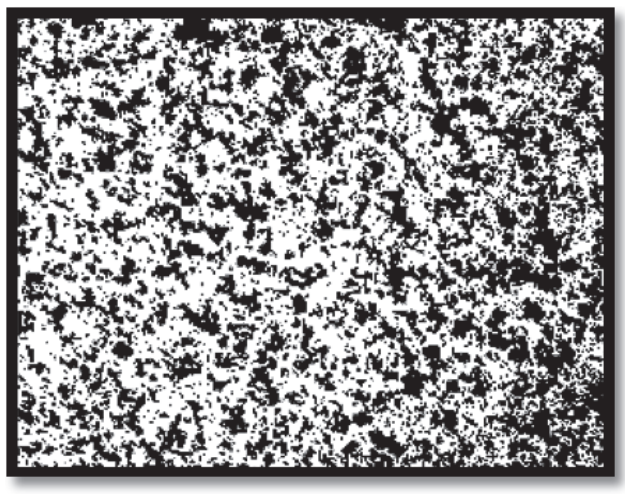

$a / a$

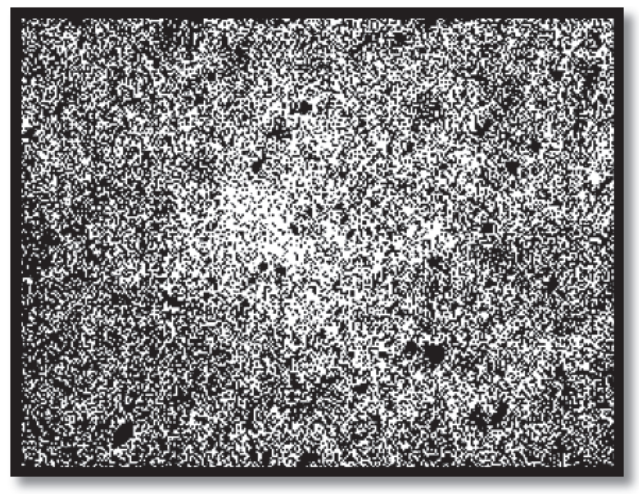

$\sigma / b$

Рис. 1. Микроизображения дисперсий диоксида титана в воде (а) и в 10\%-ном растворе пленкообразующего (б) при кратности увеличения $\times 350$

Fig. 1. Microimages of dispersion of titanium dioxide in water (a) and in $10 \%$ solution of film-forming (b) at magnification of $\times 350$

По результатам предварительных испытаний на пигментном диоксиде титана было установлено, что при заданной кратности увеличения компьютерно-оптической системы $\times 350$ наилучший эффект с точки зрения воспроизводимости и точности результатов обеспечивается при его содержании в водных суспензиях на уровне $1 \%$.

Развитие процессов дезагрегации (агрегации) контролировали по изменению среднестатистического размера твердофазных дисперсий $(d$, мкм) и фракционного состава $(P, \%)$ на фиксированной площади $(S$ обрабатываемого изображения. Вышеуказанные режимы пробоподготовки учитывали при проведении исследований. Диспергирующий эффект поверхностно-активных полимеров устанавливали в водных суспензиях с $1 \%$-м содержанием твердой фазы. В суспензиях варьировали количественные содержания водной дисперсии акрилового полимера от 0 до 30 \% и полимерных ПАВ от 0 до 4 г/дм ${ }^{3}$.

\section{Результаты и их обсуждение}

Микроизображения дисперсий диоксида титана в воде (рис. $1, a)$ и в водном растворе пленкообразующего (рис. 1, б), а также соответствующие им диаграммы, отражающие распределение частиц пигмента по фракциям, представлены на рис. 1, 2.

В растворителе содержание мелких фракций (размером частиц $\leq 44$ мкм) не превышает $52 \%$. При введении акрилового полимера в воду происходит частичное разрушение крупных агрегатов (в интервалах 45-63; 64-99 мкм), сопровождающееся увеличением содержания до $67 \%$ мелких фракций. Этот процесс обусловлен генерацией расклинивающего давления за счет диффузии пленкообразующего по границам отдельных частиц; на этой стадии в первую очередь дезагрегируют частицы, связанные в основном по точечным и лишь затем по более прочным линейным и плоскостным контактам [20].

Введение в композиции Glide 100 и Dispers715w улучшает диспергирование пигмента, рис. 3.

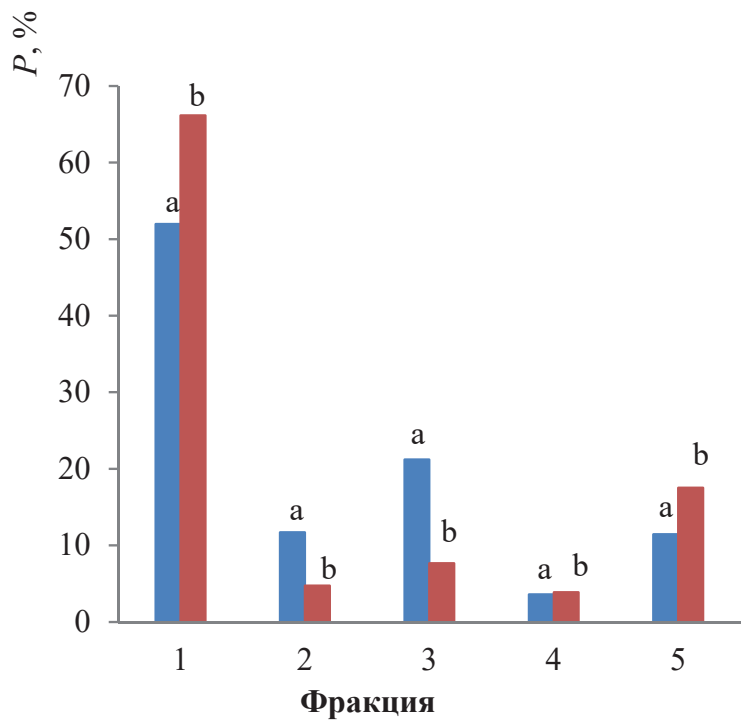

Фракции, мкм: 1 - 44; 2 - 63; 3 - 99; 4 - 140; 5 - 198

Рис. 2. Дифференциальные кривые распределения по крупности фракиий твердофазных частии пигмента в воде (а) и в $10 \%$-м растворе пленкообразующего (b)

Fig. 2. Differential distribution curves for fineness of fractions of solid-phase pigment particles in water (a) and in $10 \%$ solution of film-forming $(b)$

В системе «вода-ПАВ» максимум дезагрегирующего эффекта обоих модификаторов фиксировали при их содержании на уровне 1,0 г/дм ${ }^{3}$ рис. $3, a, \sigma$, кривая 1). При этом наибольшим диспергирующим эффектом характеризовался Dispers715w. При увеличении его содержания от 0 до 1,0 г/дм ${ }^{3}$ диаметр частиц уменьшился в 3,7 раза и составил 3,5 мкм. За пределами указанного концентрационного участка $\left(C_{\text {ПАв }}>1\right.$ г/дм $\left.{ }^{3}\right)$ наблюдаются процессы агрегации, сопровождающиеся увеличением диаметра частиц пигмента от 4,5 до 11,7 мкм (Glide 100 ) и от 3,5 до 6,2 мкм (Dispers $715 \mathrm{w}$ ) при $C_{\text {ПАв }}=4$ г $/$ дм $^{3}$. Coпоставительный анализ диспергирующего эффекта исследуемых добавок в бинарных и тройных системах показал более глубокое диспергирование в воде, 

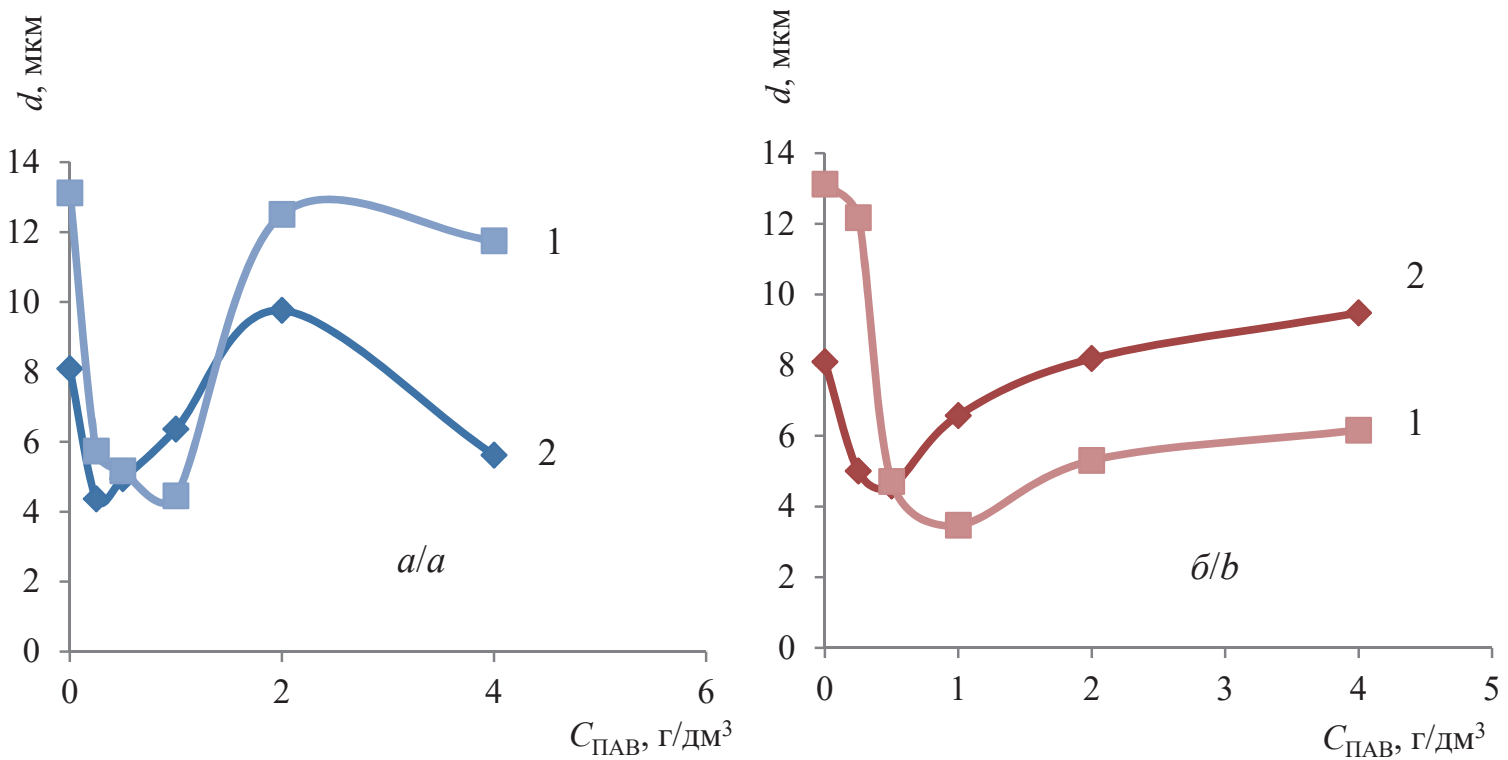

Pис. 3. Влияние содержания добавок Glide 100 (а) и Dispers 715 w (б) в воде (1) и в акриловом пленкообразующем (2) на среднестатистический диаметр частии диоксида титана

Fig. 3. Effect of the additives Glide 100 (a) and Dispers $715 \mathrm{w}(\mathrm{b})$ in water (1) and in acrylic film-forming (2) on the average diameter of titanium dioxide particle

что, очевидно, обусловлено отсутствием конкуренции со стороны макромолекул пленкообразующего. Этот факт демонстрируют зависимости $\Delta d=f\left(C_{\text {пI }}\right)$, $\Delta d-$ разность среднестатистического диаметра в суспензиях без ПАВ и его минимальным значением в присутствии добавок (рис. 4).

Судя по убыли значений $\Delta d$, с увеличением содержания пленкообразующего (от 0 до 20 \%) число макромолекул акрила, связанных с твердой поверхностью, значительно повышается, что затрудняет миграцию вводимых ПАВ в устья микрощелей и, таким образом, уменьшает нарастание деформаций и механическое разделение агрегатов под воздействием модификаторов. По мере даль-

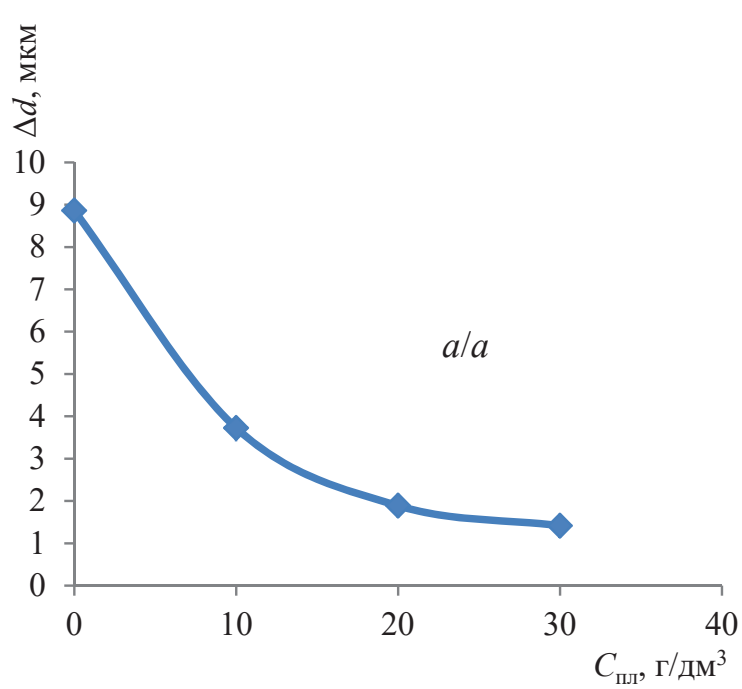

нейшего концентрирования пленкообразующего (от 20 до $30 \%$ ) фиксировали стабилизацию диспергирующего эффекта вводимых ПАВ (на уровне 1,5-2 мкм). Последнее может быть обусловлено процессами ассоциации макромолекул акрила.

Таким образом, диспергирование пигмента определяется содержанием пленкообразующего в системе и может целенаправленно регулироваться содержанием ПАВ.

По экспериментальным данным выведены обобщенные уравнения (1) и (2), описывающие влияние концентрации ПАВ и содержания пленкобразующего в суспензиях на диаметр частиц пигмента ( $d$, мкм):

\section{$\frac{\sum}{2}$}

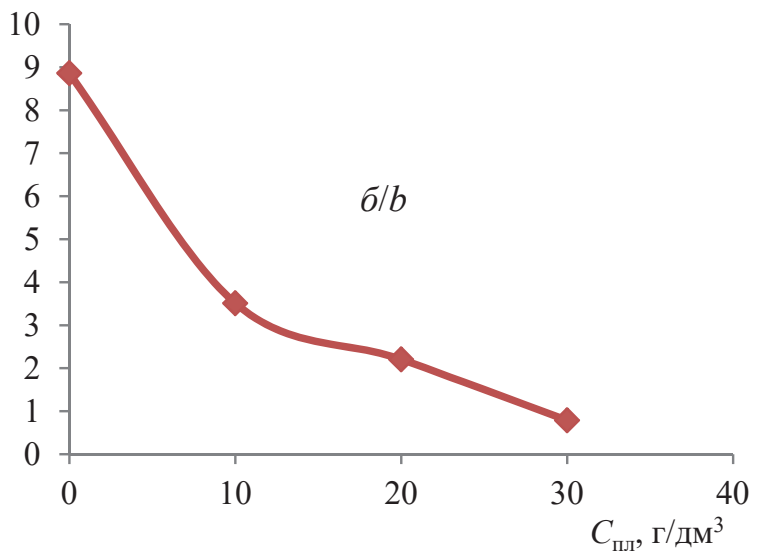

Puc. 4. Влияние содержания акрилового полимера на изленение среднестатистического диаметра частии, пиглента: а) Glide 100; б) Dispers $715 \mathrm{w}$

Fig. 4. Influence of the film-forming agent on the change in the average statistical diameter: a) Glide 100; б) Dispers715w 


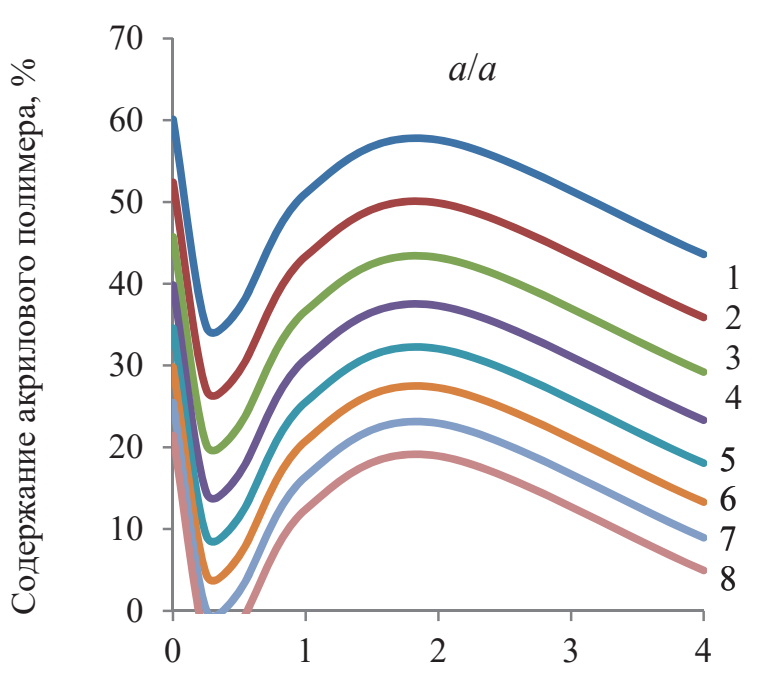

Содержание добавки, г/дм ${ }^{3}$

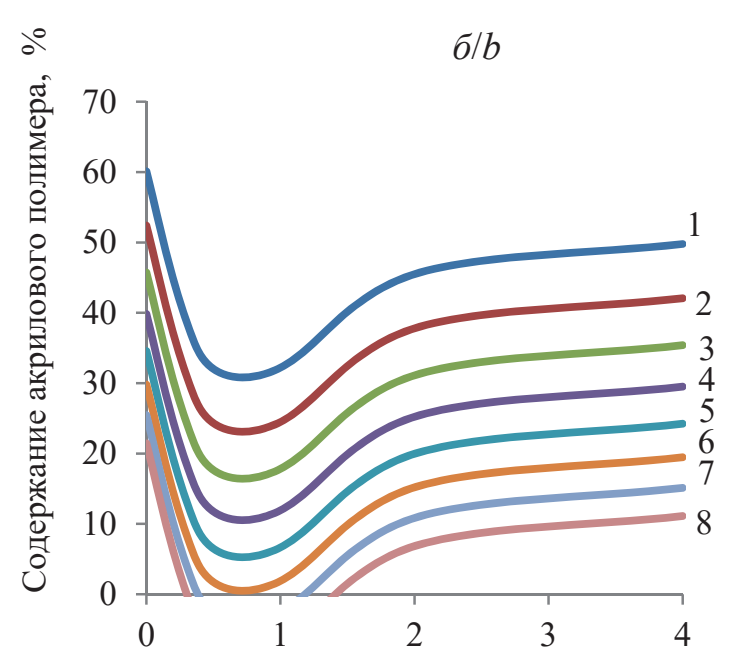

Содержание добавки, г/дм ${ }^{3}$

$d$, мкм: $1-3,0 ; 2-3,5 ; 3-4,0 ; 4-4,5 ; 5-5,0 ; 6-5,5 ; 7-6,0 ; 8-6,5$

Puс. 5. Влияние содержания акрилового полимера и добавок: Glide 100 (а) и Dispers $715 w$ (b) на среднестатистический диаметр частии пигмента

Fig. 5. Effect of the content of acrylic polymer and additives: Glide $100(a)$ and Dispers $715 \mathrm{w}(b)$ on the average diameter of pigment particle

- система «Акриловое пленкообразующее Glide $100-\mathrm{TiO}_{2} "$

$$
d=\frac{\left[\begin{array}{l}
\left(7,84-27\left(e^{C_{\mathrm{IAB}}-1}\right)\left(e^{-3,6 C_{\mathrm{IAB}}}\right)-0,03 C_{\mathrm{IAB}}^{31}\right) \times \\
\times\left(7,66 e^{-0,019 C_{\mathrm{nn}}}\right)
\end{array}\right]}{5,97} ;
$$

- система «Акриловое пленкообразующее Dispers $715 \mathrm{w}-\mathrm{TiO}_{2}$ "

$$
d=\frac{\left[\begin{array}{l}
\left(7,84-14\left(e^{C_{\mathrm{IAB}}-1}\right)\left(e^{-2 C_{\Pi \mathrm{AA}}}\right)-0,1 C_{\Pi \mathrm{AB}}^{1,8}\right) \times \\
\times\left(7,5 e^{-0,02 C_{\mathrm{nn}}}\right)
\end{array}\right]}{5,89},
$$

где $C_{\text {ПАв }}$ - содержание ПАВ в композиции, г/ дм³ $^{3}$; $C_{\text {пл }}$ - содержание акрилового полимера в композиции, \% .

На основе обобщенных уравнений (1) и (2) получены номограммы (рис. 5), позволяющие определять значения вышеуказанных параметров для достижения фиксированных значений диаметра частиц пигмента. Так, значения $d=4$ мкм при содер-

\section{СПИСОК ЛИТЕРАТУРЫ}

1. Bahadori A. Essentials of Coating, Painting, and Lining for the Oil, Gas and Petrochemical Industries. - Lismore, NSW, Australia: Gulf Professional Publishing, 2015. -830 p.

2. Offshore Pipelines / G. Boyun, S. Shanhong, A. Ghalambor, R.L. Tian. - Oxford, UK: Gulf Professional Publishing, 2014. $277 \mathrm{p}$.

3. Papavinasam S. Corrosion Control in the Oil and Gas Industry. Ottawa, Ontario, Canada: Gulf Professional Publishing, 2014. $1020 \mathrm{p}$.

4. Fairhurst D. Coatings for Structures in Contact with the Ground, Reference Module in Materials Science and Materials Engineering. - Dublin, Ireland: Elsevier Inc., 2016. - 306 p. жании акрилового полимера в системе $25 \%$ может быть достигнуто при концентрации ПАВ 0,19-0,30 г/дм ${ }^{3}$ соответственно для Dispers 715w и Glide 100. С увеличением содержания пленкообразующего $(30 \%)$ тот же размер частиц может быть достигнут при меньшей концентрации ПАВ Dispers $715 \mathrm{w} \quad\left(C_{\text {ПАВ }}=0,17 \mathrm{\Gamma}_{/ \mathrm{дм}^{3}}\right)$ и Glide 100 $\left(C_{\Pi \text { ПАВ }}=0,2\right.$ г $/$ дм $\left.^{3}\right)$.

\section{Выводы}

1. Изучено влияние двух добавок на диспергирование пигмента в водной акриловой эмали. Показано, что Glide100 и Dispers715w при содержании в композиции от 0,25 до 0,5 г/дм ${ }^{3}$ улучшают диспергирование пигмента. Наиболее эффективной добавкой является Dispers715w, при этом диаметр частиц пигмента уменьшается в два раза (с 8 до 4 мкм).

2. Выведены уравнения, описывающие влияние содержания и вида добавки на диаметр частиц пигмента, и на их основе построены номограммы.

5. New generation decorative paint technology / A. Overbeek, F. Buckmann, E. Martin, P. Steenwinkel, T. Annable // Progress in Organic Coatings. - December 2003. - V. 48. - Iss. 2-4. - P. 125-139.

6. Ребиндер П.А. Поверхностные явления в дисперсных системах: Сб. Научных трудов. - М.: Наука, 1979. - Т. 1. - 450 с.

7. Ребиндер П.А. Физико-химическая механика дисперсных структур. - М.: Знание, 1958. - Cep. 1V. - № 34. - 64 c.

8. Яковлев А.Д. Химия и технология лакокрасочных покрытий. - Л.: Химия, 1989. - 382 с.

9. Таубман А.Б., Толстая С.Н., Бородина В.Н. Адсорбционное модифицирование наполнителей и пигментов и структурообразования в растворах полимеров // ДАН СССР. - 1962. T. 142. - № 2. - C. 407-410. 
10. Таубман А.Б., Никитина С.Н., Толстая С.Н. Поверхностно-активные вещества в физико-химии и технологии полимеров // Журнал всесоюзного химического общества им. Д.И. Менделеева. - 1966. - Т. XI. - № 4. - 387 с.

11. Role of surfactants on stability of iron oxide yellow pigment dispersions / Chandrashekara R. Haramagatti, Priya Dhande, Ritesh Bhavsar, Ajinkya Umbarkar, Amit Joshi // Progress in Organic Coatings. - 2018. - V. 120. - P. 260-265.

12. Faouzi Nsib, Naceur Ayed, Yves Chevalier. Selection of dispersants for the dispersion of C.I. Pigment Violet 23 in organic medium // Dyes and Pigments. - 2007. - V. 74. - Iss. 1. P. $133-140$.

13. Dongjie Liu, Qinghui Wang, Jinjia Wei. Experimental study on drag reduction performance of mixed polymer and surfactant solutions // Chemical Engineering Research and Design. - April 2018. - V. 132. - P. 460-469.

14. Influence of surfactant and electrolyte concentrations on surfactant adsorption and foaming characteristics / Nurudeen Yekeen, Muhammad A. Manan, Ahmad Kamal Idris, Ali Mohamed Samin // Journal of Petroleum Science and Engineering. - 20 January 2017. - V. 149. - P. 612-622.

15. Sanatkaran N., Masalova I., Malkin A.Ya. Effect of surfactant on interfacial film and stability of highly concentrated emulsions stabilized by various binary surfactant mixtures // Colloids and Surfaces A: Physicochemical and Engineering Aspects. - 5 November 2014. - V. 461. - P. 85-91.

16. Surface activity of cationic surfactants, influence of molecular structure / P. Grażyna, A. Hamerska-Dudra, A. Kazimiera, K.A. Wilk, P. Warszyński // Colloids and Surfaces A: Physicochemical and Engineering Aspects. - 5 August 2010. V. 365. - Iss. 1-3. - P. 215-221.

17. Aguirreurreta Z., De la Cal J.C., Leiza J.R. Preparation of high solids content waterborne acrylic coatings using polymerizable surfactants to improve water sensitivity // Progress in Organic Coatings. - November 2017. - V. 112. - P. 200-209.

18. Kumar V., Coluccelli N., Polli D. Molecular and Laser Spectroscopy. - India: Elsevier, 2018. - 362 p.

19. Болатбаев К.Н., Дюрягина А.Н., Островной К.А. Модифицирование композитов поверхностно-активными веществами. - Петропавловск: Изд-во СКГУ, 2005. - 184 с.

20. Fırat Karakaş, Mehmet S. Çelik. Stabilization mechanism of main paint pigments // Progress in Organic Coatings. - 2018. V. 123. - P. 292-298.

Поступила 10.11.2018 2.

\section{Информация об авторах}

Дюрягина А.Н., кандидат химических наук, доцент, заведующая кафедрой химии и химических технологий Северо-Казахстанского Университета им. М. Козыбаева.

Луиенко A.A., магистрант кафедры химии и химических технологий Северо-Казахстанского Университета им. М. Козыбаева.

Тюканько В.Ю., кандидат технических наук, $\mathrm{PhD}$ химии, инженер-технолог $\mathrm{AO}$ «Казнефтегазмаш» по лакокрасочным покрытиям. 
UDC 661.1:541.18

\title{
STUDY OF THE DISPERSE EFFECT OF POLYMERIC SURFACE-ACTIVE SUBSTANCES IN ACRYLIC DISPERSIONS USED FOR PAINTING OIL WELL ARMATURE
}

\section{Antonina N. Dyuryagina',}

adyuryagina@inbox.ru

\author{
Aida A. Lutsenko', \\ |-a.13@mail.ru

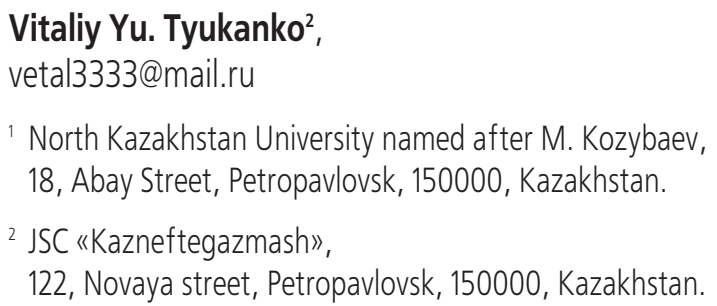

The relevance of the work is caused by the need to develop new environmentally friendly water-dispersed paints with increased operating life, according to the strict requirements of PJSC «Rosneft» to protect wellhead valves of oil wells against atmospheric corrosion. In modern practice of corrosion protection of wellhead valves in oil and gas wells and pipelines protection from damaging effects of atmospheric environments the paint and varnish based insulating coatings are widespread. Due to the tightening of environmental requirements in many countries, the use of water-based coatings has increased. So one of the largest manufacturer of wellhead valves of oil wells in the Republic of Kazakhstan - JSC "Kazneftegazmash» - uses acrylic coatings: primer "Unikor-M» TU 2316-002-031953544-96 and paint "Akrem-Metal» TU 2316-003-0-31953544-96, for painting their products waterborne. However, the main Russian oil and gas companies, in particular Rosneft, Gazprom and others, recently sharply tightened the requirements for the term of protective resource of paint coatings. Thus, according to the technological instruction of PJSC «Rosneft» № P2-05 TI-0002 "Anticorrosion protection of metal structures at oil and gas production facilities, oil and gas processing and oil products supply of the company» the minimum protective resource of paint coatings, depending on the operating conditions, is not less than 10 years. And the acrylic water-soluble coatings used by JSC "Kazneftegazmash» provide a protective resource of coatings, depending on the operating conditions, not more than 5 years. Therefore, we have attempted to increase the time of protective resource of the paint coating by obtaining a more uniform/dispersed distribution of the pigment in the polymer matrix, through the use of surfactants.

The main aim of the study was to increase the protective resource of acrylic paint, based on the study of the influence of polymer surfactants (surfactants) on dispersion of pigment (titanium dioxide) in the aqueous dispersion of acrylic polymer.

Methods: computer-optical microscopy and mathematical modeling.

Results. The paper introduces the results of the study of the effect of TEGO polymer surfactants: Glide 100 (polyether-siloxane copolymer) and Dispers $715 \mathrm{w}$ (sodium polyacrylate), on titanium dioxide (grade R-02) dispersion in aqueous acrylic composition. It was shown that Glide 100 and Dispers $715 \mathrm{w}$ with a content of 0,25 to $0,5 \mathrm{~g} / \mathrm{dm}^{3}$ in the composition improve pigment dispersion. The most effective additive is Dispers 715W, while the diameter of the pigment particles is reduced almost twice (from 8 to 4 microns). The authors have derived the equations describing the influence of content and type of surfactant on the particle diameter of the pigment, and based on the equations built the nomograms. The obtained coatings are characterized by more dispersed distribution of the filler in the polymer matrix, which significantly increases the protective resource of the paint material. The developed coatings can be used for painting wellhead valves of oil wells.

\section{Key words:}

Protective coatings, coatings, protection of oil well armature from corrosion, surface-active substances, dispersion, water-acrylic dispersion, titanium dioxide, suspension.

\section{REFERENCES}

1. Bahadori A. Essentials of Coating, Painting, and Lining for the Oil, Gas and Petrochemical Industries. Lismore, NSW, Australia, Gulf Professional Publishing, 2015. 830 p.

2. Boyun G., Shanhong S., Ghalambor A., Tian R.L. Offshore Pipelines. Oxford, UK, Gulf Professional Publishing, 2014. 277 p.

3. Papavinasam S. Corrosion Control in the Oil and Gas Industry. Ottawa, Ontario, Canada, Gulf Professional Publ., 2014. 1020 p.

4. Fairhurst D. Coatings for Structures in Contact with the Ground, Reference Module in Materials Science and Materials Engineering. Dublin, Ireland, Elsevier Inc., 2016. 306 p.

5. Overbeek A., Buckmann F., Martin E., Steenwinkel P., Annable T. New generation decorative paint technology. Progress in $\mathrm{Or}$ ganic Coatings, December 2003, vol. 48, Iss. 2-4, pp. 125-139.

6. Rebinder P.A. Poverkhnostnye yauleniya $v$ dispersnykh sistemakh. Sbornik nauchnyih trudov [Surface phenomena in disperse systems. Collection of scientific papers]. Moscow, Nauka Publ., $1979.450 \mathrm{p}$.

7. Rebinder P.A. Fiziko-khimicheskaya mekhanika dispersnykh struktur [Physico-chemical mechanics of disperse structures]. Moscow, Znanie Publ., 1958. 64 p.

8. Yakovlev A.D. Khimiya i tekhnologiya lakokrasochnykh pokryitiy [Chemistry and technology of paint and varnish coatings]. Leningrad, Khimiya Publ., 1989. 382 p.

9. Taubman A.B., Tolstaya S.N., Borodina V.N. Adsorbtsionnoe modifitsirovanie napolniteley i pigmentov i strukturoobrazovaniya $\mathrm{v}$ rastvorakh polimerov [Adsorption modification of fillers and pigments and structure formation in polymer solutions]. DAN SSSR, 1962, vol. 142, no. 2, pp. 407-410.

10. Taubman A.B., Nikitina S.N., Tolstaya S.N. Poverkhnostno-aktivnye veshchestva $\mathrm{v}$ fiziko-khimii i tekhnologii polimerov [Surface-active substances in physics and chemistry and technology of 
polymers]. Zhurnal vsesoyuznogo khimicheskogo obshchestva im. D.I. Mendeleeva, 1966 , vol. XI, no. 4, pp. 387.

11. Chandrashekara R. Haramagatti, Priya Dhande, Ritesh Bhavsar, Ajinkya Umbarkar, Amit Joshi. Role of surfactants on stability of iron oxide yellow pigment dispersions. Progress in Organic Coatings, 2018, vol. 120, pp. 260-265.

12. Faouzi Nsib, Naceur Ayed, Yves Chevalier. Selection of dispersants for the dispersion of C.I. Pigment Violet 23 in organic medium. Dyes and Pigments, 2007, vol. 74, Iss. 1, pp. 133-140.

13. Dongjie Liu, Qinghui Wang, Jinjia Wei. Experimental study on drag reduction performance of mixed polymer and surfactant solutions. Chemical Engineering Research and Design, April 2018, vol. 132, pp. 460-469.

14. Nurudeen Yekeen, Muhammad A. Manan, Ahmad Kamal Idris, Ali Mohamed Samin. Influence of surfactant and electrolyte concentrations on surfactant adsorption and foaming characteristics. Journal of Petroleum Science and Engineering, 20 January 2017, vol. 149, pp. 612-622.

15. Sanatkaran N., Masalova I., Malkin A.Ya. Effect of surfactant on interfacial film and stability of highly concentrated emulsions stabilized by various binary surfactant mixtures. Colloids and
Surfaces A: Physicochemical and Engineering Aspects, 5 November 2014, vol. 461, pp. 85-91.

16. Para G., Hamerska-Dudra A., Wilk K.A., Warszyński P. Surface activity of cationic surfactants, influence of molecular structure. Colloids and Surfaces A: Physicochemical and Engineering Aspects, 5 August 2010, vol. 365, Iss. 1-3, pp. 215-221.

17. Aguirreurreta Z., De la Cal J.C., Leiza J.R. Preparation of high solids content waterborne acrylic coatings using polymerizable surfactants to improve water sensitivity. Progress in Organic Coatings, November 2017, vol. 112, pp. 200-209.

18. Kumar V., Coluccelli N., Polli D. Molecular and Laser Spectroscopy. India, Elsevier, 2018. 340 p.

19. Bolatbaev K.N, Dyryagina A.N, Ostrounoy K.A. Modifitsirovanie kompozitov poverkhnostno-aktivnymi veshchestvami [Modification of composites by surfactants]. Petropavlovsk, NKSU ltd., $2005.184 \mathrm{p}$.

20. Firat Karakaş, Mehmet S. Çelik. Stabilization mechanism of main paint pigments. Progress in Organic Coatings, 2018, vol. 123, pp. 292-298.

Received: 10 November 2018.

\section{Information about the authors}

Antonina N. Dyuryagina, Cand. Sc., associate professor, head of the department, North Kazakhstan University named after M. Kozybaev.

Aida A. Lutsenko, graduate student, Kazakhstan University named after M. Kozybaev.

Vitaliy Yu. Tyukanko, PhD, Cand. Sc., engineer-technologist, JSC «Kazneftegazmash». 